Monika Janida

Uniwersytet M arii Curie-Skłodowskiej monika.janicka@poczta.umcs.lublin.pl

\title{
UCZEŃ ZE SPECJALNYMI POTRZEBAMI EDUKACYNYYM I NA LEKCJI JĘZYKA OBCEGO W SZKOLE PODSTAWOWEJ - ROLA NAUCZYCIELA I ŚRODOWISKA SZKOLNEGO W REALIZACJI KONCEPCJI INKLUZJI
}

\author{
The student with special educational needs in the primary language \\ classroom - the role of the teacher and school environment \\ in effecting inclusion
}

The article presents the tenets of the inclusion concept and the ways as well as the problems concerned with its implementation. Special attention has been given to primary school-students with special educational needs in the language classroom. In the article results of a research project are presented. The project had two aims. The first was to elicit the level of implementation of the inclusion concept at Polish primary schools using the example of teaching foreign languages. The other aim was to sensitise the students of applied linguistics - future language teachers - to the challenges concerned with teaching languages to children with special educational needs.

Keywords: special educational needs, inclusive didactics, foreign language teaching, primary schools

Słowa kluczowe: specjalne potrzeby edukacyjne, dydaktyka inkluzyjna (włączająca), nauczanie języków obcych, szkoły podstawowe

\section{Uwagi wstępne}

Integracja społeczna oraz wyrównywanie szans edukacyjnych to jedne z głównych celów znowelizowanej w 2004 roku Ustawy o systemie oświaty, która 
gwarantuje m.in. równy dostęp do oferty edukacyjnej dla wszystkich uczniów, także tych ze specjalnymi potrzebami edukacyjnymi ${ }^{1}$. Kim jednak jest uczeń ze SPE? Ze względu na złożoność problematyki w literaturze przedmiotu nie ma jednoznacznej definicji tego terminu. Jako pierwsza terminu special educational needs użyła w 1978 roku Mary Warnock w swoim raporcie na temat stanu edukacji w Wielkiej Brytanii. Argumentując, że określenie handicap jako medycznie opisana jednostka chorobowa jest bezużyteczne w kontekście edukacyjnym, zaproponowała mniej stygmatyzującą i uwzględniającą złożoność indywidualnych potrzeb edukacyjnych alternatywę (Warnock 1978). Z jak szerokim zbiorem zagadnień mamy do czynienia w przypadku SPE, pokazują definicje zaproponowane przez Zespół Ekspertów ds. Specjalnych Potrzeb Edukacyjnych, który został powołany w 2008 roku przez ministra edukacji narodowej. Według zespołu: „Dzieci i młodzież ze specjalnymi potrzebami rozwojowymi i edukacyjnymi to te, u których stwierdza się spektrum objawów utrudniających lub uniemożliwiających funkcjonowanie: ruchowe, sensoryczne, poznawcze, w zakresie komunikacji, emocjonalno-społeczne i/lub psychiczne, wpływających na jakość życia i pełnienie ról społecznych teraz i/lub w przyszłości. (...) [oraz] te, u których stwierdza się zagrożenie niepełnosprawnością, wszelkie dysfunkcje, dysharmonie lub niesprawności mogące mieć negatywny w pływ na dalszy rozwój" (Zaremba 2014: 15). W przypadku dzieci do 3. roku życia mówi się o specjalnych potrzebach rozwojowych, natomiast termin specjalne potrzeby edukacyjne odnosi się do dzieci i młodzieży od 3. roku życia aż do ukończenia edukacji. Według raportu M ary Warnock przynajmniej jedno na pięcioro dzieci ma SPE i wykazuje - choćby czasow o - potrzebę indywidualnego wsparcia (Warnock 1978: 41). Przeprowadzone badanie własne, którego wyniki zostaną zaprezentowane w dalszej części artykułu, wykazało, że w objętych badaniem szkołach podstawowych w jednej klasie uczy się średnio pięciu $(5,1)$ uczniów ze SPE.

Uczniowie ze SPE objęci są zgodnie z Rozporządzeniem M EN z dnia 30 kwietnia 2013 programem pomocy psychologiczno-pedagogicznej, dzięki której mogą uczestniczyć w zajęciach dydaktyczno-wyrównawczych, warsztatach, w specjalistycznych zajęciach korekcyjno-kompensacyjnych, korzystać z porad pedagogów i psychologów oraz konsultacji (Dz. U. 2013, p0z. 532, §7). Wsparcie ucznia ze SPE powinno się jednak odbywać - zgodnie z założeniami Ustawy - również podczas bieżącej pracy na lekcji. Stawia to przede wszystkim przed nauczycielami przedmiotu szereg wyzwań. Wskazują na to wyniki badań. Do największych trudności, jakie napotyka praca z uczniami ze SPE w klasach integracyjnych, należą: zbyt duże zróżnicowanie rodzajów niepełnosprawności

${ }^{1}$ W dalszej części artykułu na określenie specjalnych potrzeb edukacyjnych będzie używany skrót SPE. 
Uczeń ze specjalnymi potrzebami edukacyjnymi na lekcji języka obcego...

uczniów w jednej klasie, brak specjalistycznych pomocy dydaktycznych dla uczniów niepełnosprawnych, zbyt mała pomoc udzielana ze strony specjalistycznych placówek, niewystarczające przygotowanie materialno-organizacyjne placówki do kształcenia integracyjnego, zbyt mała liczba godzin przeznaczona na zajęcia rewalidacyjne, zbyt duża liczba uczniów niepełnosprawnych i pełnosprawnych w jednej klasie (Pachowicz 2011: 127). Na podobne problemy wskazują nauczyciele języków obcych pracujący w szkołach ogólnodostępnych. Jako najczęściej występujące trudności w realizacji idei integracji wymieniają m.in.: zbyt liczne klasy, brak możliwości dodatkowej pracy indywidualnej, trudny dostęp do informacji na temat danej niepełnosprawności, brak materiałów metodycznych przeznaczonych do pracy z dzieckiem niepełnosprawnym, brak uregulowań prawnych i wskazań metodycznych dotyczących specjalnych programów przedmiotowych dla uczniów z deficytami, brak bądź utrudniona współpraca z rodzicami/ opiekunami dziecka, brak akceptacji kolegów z klasy (Karpińska-Szaj 2011: 67-68).

Nauka uczniów w klasach integracyjnych generuje podobne problemy jak nauka w klasach ogólnodostępnych. Ponadto często nie przyczynia się do faktycznej integracji uczniów niepełnosprawnych i pełnosprawnych oraz wyrównywania szans edukacyjnych. Zdarza się wręcz, że klasy integracyjne stają się swoistego rodzaju gettami, do których uczęszczają głównie uczniowie z deficytami i do których rodzice nie chcą posyłać swoich dzieci, o ile te nie mają trudności w nauce. Stąd coraz częściej mówi się o konieczności zastąpienia koncepcji integracji koncepcją inkluzji (włączania). W koncepcji tej różnorodność postrzegana jest jako wartość. Przebywając w heterogenicznym środowisku uczniowie rozwijają się, doświadczając swojego indywidualizmu przede wszystkim poprzez budowanie pozytywnych relacji z innymi. Inkluzja sprzeciwia się wszelkim formom dyskryminacji i marginalizacji, natomiast domaga się możliwości samostanowienia i współu czestniczenia dla wszystkich.

\section{Koncepcja dydaktyki inkluzyjnej (włączającej)}

Ze względu na złożoność problematyki nie istnieje jedna spójna definicja inkluzji. Próby jej scharakteryzowania sprowadzają się raczej do opracowania katalogów cech. Szumski uznaje następujące cechy za konstytutywne dla dydaktyki inkluzyjnej: szkoła rejonowa kształci wszystkich uczniów, także tych z niepełnosprawnością i specjalnymi potrzebami edukacyjnymi; uczniowie stanowią heterogeniczną grupę; program nauczania jest wspólny dla wszystkich uczniów, ale jest jednocześnie elastycznie dopasowywany do ich potrzeb edukacyjnych; nauczyciel klasowy jest wspierany przez zespół specjalistów; system pomocy specjalnej jest w sposób elastyczny i zindywidualizowany dostosowany 
do potrzeb poszczególnych uczniów (Szumski 2011: 17). Reich wymienia 10 elementów, które stanowią fundament inkluzyjnej szkoły. Należą do nich (1) nauczyciele, działający w dobrze wspótpracujących zespołach, prezentujący postawę otwartości wobec różnorodności; (2) szkoła, która gwarantuje równość szans wszystkim uczniom, bez względu na ich pochodzenie, płeć czy trudności w nauce, i która współpracuje z domem rodzinnym uczniów; (3) podstawy programowe i programy nauczania, które umożliwią każdemu uczniowi rozwój kompetencji i osiągnięcie indywidualnego mistrzostwa, uwzględniając przy tym jego zainteresowania i potencjał; (4) całodzienna opieka w szkole, zapewniająca zdrowe żywienie, ruch i wypoczynek uczniów ${ }^{2}$, umożliwiająca aktywne i konstruktywne uczenie się w inspirującym środowisku; (5) tworzenie przyjaznego środowiska uczenia się, poprzezjasne określanie celów, które uczeń ma osiągnąć, i udzielanie informacji zwrotnych pomocnych w planowaniu dalszej nauki, efektywne zarządzanie czasem lekcji, umożliwianie współpracy i umiejętne wykorzystanie mediów; (6) wspieranie uczniów ze SPE przy założeniu, że wszyscy ludzie mają potrzebę indywidualnego wsparcia; (7) zróżnicowane ocenianie, tączenie nauczania z ocenianiem kształtującym, wspierającym rozwój ucznia, uwzględniającym elementy samooceny; (8) odpowiednio zaplanowana architektura szkolna, pozbawiona barier, dysponująca m.in. miejscami spotkań dla uczniów, kącikami cichej nauki i pokojami konsultacji; (9) szkoła otwarta na zewnątrz, współpracująca z dzielnicą, gminą, na rzecz której uczniowie się angażują; (10) wsparcie ze strony ekspertów, korzystanie z zewnętrznej ewaluacji, nastawienie na zmianę i ciągły rozwój (Reich 2014). Al-Khamisy (2013) stawia pomiędzy edukacją włączającą a edukacją dialogu znak równości, podkreślając, że przestrzeń edukacyjna stanowi przestrzeń dialogu i daje się rozpatrywać w trzech wymiarach: horyzontalnym, społecznym i wertykalnym. Wymiar horyzontalny dotyczy zasobów materialnych przestrzeni szkolnej: wyposażenia, architektury, układu sal czy otoczenia. Wszystko to determinuje bez wątpienia formy komunikacji pomiędzy nauczycielem a uczniami. Drugi wymiar ma charakter społeczny i dotyczy zasobów intelektualnych i moralnych społeczności szkolnej. Zaliczyć do nich można szeroko rozumiane kompetencje nauczycieli, uczniów i rodziców. Natomiast wymiar wertykalny stanowi „całokształt społecznie uznawanych i przyswojonych w zbiorowości szkolnej norm regulujących zachowania jej członków, zwane też etosem czy misją szkoły” (Al-Khamisy 2013: 92). Na tym tle ma miejsce „partnerstwo edukacyjne", rozwijające się jako pogłębiona relacja nastawiona na współpracę podmiotów zaangażowanych w edukację (tamże).

\footnotetext{
${ }^{2}$ Autorka odnosi się do niemieckiego systemu edukacji, w którym szkoły sprawujące całodzienną opiekę nad uczniami, posiadające świetlicę, stołówkę oraz oferujące zajęcia wyrównawcze dla uczniów, wciąż nie są oczywistością.
} 
Uczeń ze specjalnymi potrzebami edukacyjnymi na lekcji języka obcego...

Powyższe rozważania pokazują, że realizacja koncepcji inkluzji musi mieć charakter systemowy i powinna być realizowana przez szeroko rozumiane środowisko społeczno-szkolne. Ponieważ jednak wzięcie pod lupę wszystkich aspektów udanej inkluzji przekraczałaby możliwości tej publikacji, analiza zagadnienia ograniczy się do omówienia roli nauczyciela języka obcego oraz szkoły jako instytucji, w której dydaktyka włączająca jest realizowana.

\section{Postawy nauczycieli a realizacja koncepcji inkluzji}

John Hattie (2015: 35) stwierdza na podstawie przeprowadzonych przez siebie metaanaliz, obejmujących ponad 900 badań edukacyjnych, że głównymi rozgrywającymi procesu uczenia się i nauczania są nauczyciele, gdyż to ich oddziaływanie ma największy efekt i wpływ na to, jak uczniowie rozwijają swoje umiejętności uczenia się. Oddziaływanie to odbywa się poprzez angażowanie się z entuzjazmem i pasją we wskazywanie uczniom kierunków rozwoju. Skuteczne oddziaływanie na uczniów nie jest możliwe bez zapewnienia informacji zwrotnych, dzięki którym każdy uczeń będzie mógł odnotować rozwój i osiągać cele określone w programie nauczania, oraz bez jasnych kryteriów pozwalających stwierdzić, czy odniósł sukces. Wreszcie: skuteczni nauczyciele pozwalają uczniom na konstruowanie (a nie jedynie odtwarzanie) wiedzy, zaś błędy uczniów traktują jako doskonałą okazję do uczenia się (Hattie 2015: 46-47).

W koncepcji szkoły inkluzyjnej nauczyciel odgrywa doniosłą rolę w zapewnieniu skuteczności procesów uczenia się. Jak pokazują metaanalizy Johna Hattie, kompetencje merytoryczne nauczyciela nie są jednak najważniejsze dla skuteczności jego oddziaływania na uczenie się uczniów. Dużo silniejszy efekt wykazuje dobra, pełna zaufania i wyrozumiałości dla błędów atmosfera panująca w klasie (Hattie 2015: 131-132). Reich (2014) twierdzi podobnie jak Hattie, że w dydaktyce inkluzyjnej warstwa relacji ma prymat nad warstwą treści, ponieważ to relacje wpływają na sposób i efektywność przekazywania tych drugich. Nauczyciel skutecznie realizujący ideę inkluzji jest nastawiony na wyrównywanie szans edukacyjnych. Posiada wysokie kompetencje osobiste: komunikatywność, chęć niesienia pomocy, poczucie odpowiedzialności, jest zaintereso wany sytuacjami pedagogicznymi i otwarty na pedagogiczne eksperymentowanie. Potrafi zarządzać czasem i pracować w zespole, posiada kompetencje planowania i ewaluacji. Posiada wysokie kompetencje fachowe, poszerzane i modyfikowane ze względu na potrzeby zróżnicowanych grup. Ma podstawową wiedzę na temat psychologiczno-pedagogicznych i społecznych uwarunkowań procesu uczenia się, psychologii rozwojowej, diagnostyki pedagogicznej, a także ogólne kwalifikacje dotyczące pedagogiki specjalnej (Reich 2014: 86). Wiedza ta może przybierać postać kompetencji terapeutycznej, co 
pozwoli nauczycielowi na prawidłowe interpretowanie diagnoz specjalistów oraz skuteczne organizowanie edukacji dzieci o różnych potrzebach edukacyjnych. Kompetencje terapeutyczne powinny ułatwić mu także m.in. opracowanie indywidualnych programów nauczania, dobór treści programu kompensacyjnego, stosowanie odpowiednich technik terapeutycznych, używanie właściwych komunikatów werbalnych i pozawerbalnych oraz obserwację czynną i umiejętność konstruowania na jej podstawie adekwatnych wniosków. Ważną umiejętnością sytuującą się w ramach kompetencji terapeutycznej jest także umiejętność słuchania drugiej osoby (por. Al-Khamisy 2015: 17-18). Nauczyciel w szkole inkluzyjnej jest gotów do przejęcia odpowiedzialności za działania swoje i zespołu. Krytycznie obserwuje własną praktykę zawodową i jest otwarty na poszukiwanie i wdrażanie lepszych rozwiązań. Wykazuje się gotowością do kształcenia ustawicznego, otwartością na wymianę doświadczeń i na zmiany mające na celu poprawę jakości kształcenia włączającego (Reich 2014: 86). Nauczyciel cechujący się postawą inkluzyjną ukierunkowuje swoje działania na uczniów. Poprzez stosowanie form uczenia się nastawionych na współpracę i komunikację zachęca wszystkich uczących się - bez względu na ich potencjał wyjściowy - do poszukiwania własnych dróg efektywnego uczenia się oraz do współdziałania. Jest także gotów do modyfikowania swoich metod pracy w taki sposób, aby pomóc uczniom w osiąganiu indywidualnego mistrzostwa i w rozwoju (Reich 2014: 90).

\section{4. Środowisko szkolne a realizacja koncepcji inkluzji}

M odel Lokalnej Współpracy na rzecz dzieci ze SPE podkreśla, że aby działania na rzecz dziecka przynosiły pozytywne efekty, muszą mieć charakter całościowy, uwzględniający wszystkie aspekty jego życia. Im więcej instytucji zaangażowanych we współpracę na rzecz ucznia ze SPE, włączając w to oprócz szkoły także inne instytucje wsparcia, jak poradnię psychologiczno-pedagogiczną, placówki doskonalenia nauczycieli, uczelnie wyższe, biblioteki pedagogiczne, pomoc społeczną czy organizacje pozarządowe, tym skuteczniejsze są te działania. Organizatorem i koordynatorem działań na rzecz dziecka ze SPE powinna być jednostka samorządu terytorialnego. W modelu tym ważną rolę odgrywa współpraca w rodzicami (Czopińska, Szumilas 2015).

Działania systemowe mają ogromne znaczenie dla jakości wsparcia nie tylko z perspektywy ucznia, ale także z perspektywy nauczyciela. Nauczyciel, który samotnie musi stawić czoła wyzwaniom, jakie niesie praca z uczniem ze SPE, może poczuć się zagubiony, w skrajnych przypadkach nawet wypalony. Dlatego kluczową rolę odgrywa współdziałanie w zespole nauczycieli i specjalistów, które pozwala na systemowe planowanie pracy z uczniem ze SPE oraz wymianę doświadczeń. Współpraca z innymi nauczycielami czy specjalistami 
Uczeń ze specjalnymi potrzebami edukacyjnymi na lekcji języka obcego...

ma także efekt odciążający nauczyciela, pozwalający mu na nabranie dystansu do własnych działań, co jest nie bez znaczenia w szczególności w przypadku niepowodzeń lub braku widocznych efektów w procesie nauczania (Reich 2014: 94). Zespół ma większą kompetencję niż pojedynczy człowiek. Praca w zespole ułatwia dobór strategii nauczania, zaś wymiana doświadczeń dotyczących ich wdrażania pozwala zespołom na dokonywanie korekt w trakcie pracy (Hattie 2015: 116-117) i może przyczynić się do wzbogacenia praktyki dydaktycznej.

Optymalny model współpracy to taki, w którym nauczyciel przedmiotu działa wspólnie z pedagogiem (specjalnym). W modelu tym nauczyciel przedmiotu informuje o aktualnych celach nauczania, realizowanych tematach oraz terminach sprawdzianów. Pedagog (specjalny) informuje o indywidualnych potrzebach poszczególnych uczniów oraz proponuje konkretne sposoby ich wsparcia. Nauczyciel przedmiotu uzupełnia te propozycje, informuje o konfliktach w klasie, o tym, z kim powinien współpracować dany uczeń, a z kim nie. Omawiane są także reguły pracy w klasie oraz sposoby wspierania poszczególnych uczniów (Pertek, Scheler 2016: 23). Polecane z punktu widzenia dydaktyki włączającej jest współprowadzenie zajęć (co-teaching) przez dwóch nauczycieli lub nauczyciela przedmiotu i nauczyciela wspomagającego. Jedną z form wsparcia pracy nauczyciela może stanowić superwizja koleżeńska3 ${ }^{3}$, do której zalet należy m.in. lepsze poznanie siebie, lepsze poznanie problemów wychowanków, uczenie się większej wrażliwości, uważności w ich obserwowaniu i ocenianiu oraz poczucie wzajemnego wsparcia w sytuacjach trudnych (Seredyńska 2013: 111). Innymi korzystnymi dla nauczania włączającego formami nauczania są asystentura, gdy jeden nauczyciel prowadzi zajęcia, zaś drugi wspiera go w sytuacjach, gdy jest to niezbędne, oraz nauczanie w podgrupach, gdy duża grupa uczniów zostaje podzielona na dwie mniejsze, które realizują nieco inny materiał lub pracują w różnym tempie. Zalecanymi technikami nauczania są tzw. otwarte formy pracy: stacje uczenia się lub praca samodzielna, które uczniom ze SPE pozwalają w sposób zindywidualizowany pracować w odpowiednim dla nich tempie (Reich 2014: 95). Scruggs, Mastropieri i M cDuffie (2007: 403-405) wskazują na uwarunkowania efektywnego współprowadzenia zajęć: nauczyciele nauczający w tandemie otrzymują wsparcie ze strony administracji szkoły ${ }^{4}$, współprowadzenie

3 Superwizja koleżeńska jest rodzajem profesjonalnej pomocy, w której osoba doświadczona w konsultowaniu udziela wskazówek innym pracownikom. Podstawowym zadaniem superwizji koleżeńskiej jest dawanie pracownikom informacji zwrotnych o ich pracy, stylach wchodzenia w relacje, mechanizmach obronnych, silnych i słabych stronach osobowych (Seredyńska 2013: 103).

${ }^{4}$ Musi ono dotyczyć choćby zaprojektowania planu lekcji w taki sposób, aby taka współpraca była organizacyjnie możliwa. 
zajęć odbywa się na zasadzie dobrowolności, nauczyciele dobierają się samodzielnie w tandemy, współpracują na zasadach partnerskich, darząc się wzajemnym zaufaniem i szacunkiem, nauczyciele otrzymują dość czasu, aby przygotować się do współpracy i otrzymują w tym celu odpowiedni trening.

Aby nauczanie włączające mogło być skuteczne, musi mieć - jak już wspomniano - charakter systemowy. Szkoła jako instytucja powinna mieć wizję kształcenia uczniów ze SPE, zaś osoby zarządzające szkołą powinny zadać sobie pytanie, czy prowadzona przez nich placówka może stać się szkołą równych szans. Wizja szkoły dotyczy także rozumienia wartości dodanej płynącej z faktu, że uczęszczają do niej uczniowie ze SPE oraz umiejętnego wykorzystania ich obecności, np. do rozwijania kompetencji komunikacyjnych uczniów bez SPE. Prócz wizji niezbędne są także wiedza i umiejętności dotyczące metod pracy, kryteriów oceniania, dopasowania środków dydaktycznych do potrzeb i możliwości ucznia ze SPE, wsparcie ze strony domu rodzinnego lub terapeuty dziecka oraz umiejętność opracowania adekwatnego do pojawiających się trudności planu nauczania (por. Karpińska-Szaj 2011: 70; 2013: 38).

\section{Projekt badawczy}

\subsection{Cel i metodologia badania}

Przeprowadzone badanie miało dwa cele. Głównym celem badawczym była aktualizacja i pogłębienie wiedzy na temat realizacji idei inkluzji z perspektywy lekcji języka obcego w szkole podstawowej. Drugi cel miał charakter dydaktyczny. Informacje dotyczące celu badawczego były zbierane przez studentów lingwistyki stosowanej III roku studiów licencjackich podczas odbywanej w listopadzie 2015 praktyki metodycznej i stanowiły zadanie w ramach przedmiotu „dydaktyka kompensacyjna”. Celem niejako nadrzędnym realizowanego projektu było uwrażliwienie studentów na problematykę inkluzji. Zostali oni wcześniej zapoznani z problematyką SPE oraz otrzymali wskazówki do pracy z uczniami z różnymi rodzajami SPE. Studenci otrzymali także jednolity arkusz wywiadu/obserwacji z pytaniami zamkniętymi i otwartymi (patrz załącznik). Zadanie studentów polegało zbieraniu informacji na temat ucznia ze SPE (wybranego z pomocą nauczyciela, szkolnego opiekuna praktyk), który miał opinię bądź orzeczenie poradni pedagogiczno-psychologicznej, poprzez obserwację uczestniczącą (Łobocki 2006: 48) oraz przeprowadzenie wywiadów z pracownikami placówki edukacyjnej, w której odbywali praktykę. Pytania wywiadu/obserwacji dotyczyły pracy nauczyciela języka obcego, jego przygotowania do pracy z uczniami ze SPE oraz gotowości do wdrażania koncepcji dydaktyki włączającej. W arkuszach uwzględniono także pytania dotyczące 
Uczeń ze specjalnymi potrzebami edukacyjnymi na lekcji języka obcego...

szkoły jako placówki oraz atmosfery w klasie, przede wszystkim postaw szkolnych koleżanek i kolegów wobec ucznia ze SPE. Wskaźniki dotyczące kompetencji nauczyciela obejmowały stosowanie przez niego technik nauczania wspomagających naukę ucznia ze SPE, dopasowanie wymagań i kryteriów oceniania do indywidualnych potrzeb i możliwości ucznia ze SPE oraz poziom wiedzy na temat pracy z uczniem ze SPE, co w ankiecie zostało zoperacjonalizowane poprzez pytanie o uczestnictwo w formach doskonalenia dotyczących pracy z uczniem ze SPE w ciągu ostatnich trzech lat. Wskaźniki dotyczące szkoły obejmowały wizję pracy z uczniem ze SPE, wsparcie nauczyciela języka obcego przez specjalistów (psychologa, pedagoga szkolnego, nauczyciela wspomagającego), wyposażenie szkoły w specjalistyczny sprzęt, pomoce dydaktyczne oraz materiały pomocne w pracy z uczniem ze SPE.

\subsection{Wyniki badania}

Uzyskano 36 protokołów dotyczących 36 uczniów ze SPE. Obserwacje i wywiady były przeprowadzone w 13 szkołach podstawowych na terenie województwa lubelskiego. Jedna ze szkół była szkołą prywatną, pozostałe placówki to szkoły ogólnodostępne bez klas integracyjnych. 32 spośród obserwowanych uczniów miało opinie bądź orzeczenia poradni psychologiczno-pedagogicznych i zostało zdiagnozowanych jako uczniowie ze SPE. Pozostałe 4 osoby nie miały opinii, ale w ocenie nauczycieli byli to uczniowie ze SPE. Najwięcej, bo aż 26 uczniów, miało opinie poradni dotyczące dysleksji, 5 uczniów - było dotkniętych ADHD. Problemy pozostałych pięciu osób dotyczyły problemów emocjonalnych (2), niepełnosprawności intelektualnej (1), trudności w uczeniu się (1) oraz trudności z koncentracją (1). Większość informacji zebrana została w oparciu o obserwacje uczestniczące oraz rozmowę z nauczycielem języka obcego - szkolnym opiekunem praktyk. 12 protokołów zawierało dodatkowo informacje na temat pracy z uczniem ze SPE zaczerpnięte w rozmowie z psychologiem lub pedagogiem szkolnym, zaś jeden - z wicedyrektorem szkoły 5 .

\section{Nauczyciele języka obcego}

Na podstawie uzyskanych dzięki protokołom danym można stwierdzić, że 86\% badanych nauczycieli języka obcego stosuje techniki pracy dostosowane do potrzeb ucznia ze SPE. Pozostali nauczyciele zaznaczyli, że w przypadku ich uczniów nie ma takiej potrzeby lub że nie jest to możliwie ze względu na dużą

\footnotetext{
${ }^{5}$ Ze względu na ograniczenia tej publikacji pominięto analizę dotyczącą klasy, atmosfery, reakcji innych uczniów na obecność w klasie ucznia ze SPE.
} 
liczebność grupy językowej. Najczęściej wymieniane metody pracy dostosowywane ze względu na trudności i możliwości uczniów ze SPE pokazuje tabela $1^{6}$.

\begin{tabular}{|l|r|}
\hline Stosowane techniki pracy & $\begin{array}{r}\% \\
\text { odpowiedzi }\end{array}$ \\
\hline $\begin{array}{l}\text { Wydłużony czas pracy lub mniejsza liczba zadań do wykonania umożliwiające } \\
\text { wolniejsze tempo pracy }\end{array}$ & $21 \%$ \\
\hline $\begin{array}{l}\text { Wizualizacje, gry językowe wspierające zapamiętywanie (memory, fiszki zobraz- } \\
\text { kami, tablica interaktywna) }\end{array}$ & $12,5 \%$ \\
\hline $\begin{array}{l}\text { Stałe monitorowanie pracy ucznia (sadzanie blisko nauczyciela, bieżąca kontrola } \\
\text { pracy ucznia, indywidualna pomoc w wykonywaniu ćwiczeń) }\end{array}$ & $12,5 \%$ \\
\hline M otywowanie ucznia do pracy poprzez wskazywanie jego mocnych stron & $12,5 \%$ \\
\hline $\begin{array}{l}\text { Przygotowywanie indywidualnych kart pracy dostosowanych do potrzeb i moż- } \\
\text { liwości ucznia }\end{array}$ & $9 \%$ \\
\hline Dzielenie materiału lub zadań na mniejsze części & $9 \%$ \\
\hline Zabawy ruchowe, umożliwienie aktywności ruchowej & $7,5 \%$ \\
\hline Wydawanie krótkich poleceń & $6 \%$ \\
\hline $\begin{array}{l}\text { Inne? (np. praca na zajęciach wyrównawczych, przestrzeganie stałego porządku } \\
\text { lekcji, wskazywanie poprawnej pisowni) }\end{array}$ & $22,5 \%$ \\
\hline
\end{tabular}

Tabela 1: Najczęściej stosowane techniki nauczania w pracy z uczniami ze SPE.

\begin{tabular}{|l|r|}
\hline Sposoby dostosowania wymagań i oceniania & $\begin{array}{r}\% \\
\text { odpowiedzi }\end{array}$ \\
\hline Wydłużenie czasu pracy na sprawdzianie & $23 \%$ \\
\hline $\begin{array}{l}\text { Ocenianie wartości merytorycznej, ignorowanie błędów ortograficznych, ni- } \\
\text { skiego poziomu graficznego pisma }\end{array}$ & $20 \%$ \\
\hline $\begin{array}{l}\text { Docenianie wszelkich starań, uwzględnianie w ocenie włożonego przez ucznia } \\
\text { wysiłku }\end{array}$ & $19 \%$ \\
\hline Mniejsza liczba zadań do wykonania na sprawdzianie & $7,5 \%$ \\
\hline $\begin{array}{l}\text { Przygotowywanie indywidualnych testów i sprawdzianów (zawierających ła- } \\
\text { twiejsze zadania) }\end{array}$ & $6 \%$ \\
\hline $\begin{array}{l}\text { Umożliwianie zaliczania ustnego zamiast pisemnego } \\
\text { Inne }{ }^{8} \text { (możliwość wielokrotnego zaliczania prac klasowych, pisanie prac domo- } \\
\text { wych na komputerze, mniejsze partie materiału do przygotowania, możliwość } \\
\text { wyboru pracy domowej przez ucznia, komentarz wyjaśniający do oceny) }\end{array}$ & $13,5 \%$ \\
\hline
\end{tabular}

Tabela 2: Najczęściej stosowane sposoby dostosowywania wymagań i kryteriów oceny w pracy z uczniami ze SPE.

${ }^{6}$ Arkusz wywiadu/obserwacji miał charakter otwarty. Ztego powodu udzielone odpowiedzi zostały pogrupowane. Techniki, które znalazły się w kategorii INNE, uzyskały mniej niż 5\% wskazań.

${ }^{7}$ Wskazania równe lub mniejsze niż 5\%.

${ }^{8}$ Wskazania równe lub mniejsze niż 5\% 
Uczeń ze specjalnymi potrzebami edukacyjnymi na lekcji języka obcego...

Ponad 80\% nauczycieli dostosowuje wymagania i sposób oceniania do możliwości i potrzeb uczniów ze SPE. Wymagania uwzględniają zalecenia poradni psychologiczno-pedagogicznej i/lub Wewnętrznego Systemu Oceniania (WSO). Odpowiedzi negatywne dotyczyły na ogół uczniów z nadpobudliwością psychoruchową bez opinii poradni ${ }^{9}$. Tabela 2 przedstawia najczęstsze sposoby dostosowywania wymagań i oceniania do potrzeb i możliwości uczniów ze SPE. Znamienne jest, że w protokołach wskazano tylko jeden raz, że ocenie towarzyszy komentarz.

Choć wiedza merytoryczna nauczyciela przedmiotu na temat niepełnosprawności nie jest najważniejsza i trudno wymagać, aby był on specjalistą od wszelkich SPE, to można założyć, że znajomość problematyki może w znacznym stopniu ułatwić planowanie oraz pracę z uczniem ze SPE, modyfikowanie programu nauczania, gdy zajdzie taka potrzeba, dostosowanie wymagań, przygotowanie adekwatnych odpowiadających potrzebom i możliwościom ucznia materiałów i pomocy dydaktycznych. Interesujące było także, skąd nauczyciele języków obcych czerpią wiedzę w tym zakresie i czy regularnie ją pogłębiają i aktualizują. Dlatego arkusz zawierał pytanie do nauczycieli języków obcych, czy i w jakich formach doskonalenia na temat SPE uczestniczyli w ciągu ostatnich trzech lat. Spośród przebadanych nauczycieli tylko 4 nie brało udziału w żadnych szkoleniach na temat pracy z uczniami ze SPE. Ponadto dwie osoby nie były pewne, czy ich udział $w$ formach doskonalenia na ten temat miał miejsce w przeciągu trzech lat, czy było to dawniej. Najwięcej respondentów (75\%) brało udział w stacjonarnych formach doskonalenia. Były to szkolenia rady pedagogicznej, warsztaty metodyczne organizowane przez ośrodki doskonalenia nauczycieli lub przez wydawnictwa edukacyjne. Można przyjąć, że jakość tych szkoleń była bardzo różna. Zaledwie trzy osoby ukończyły studia podyplomowe dotyczące diagnozy i terapii pedagogicznej. 2 osoby wskazały wysłuchanie wykładu na temat SPE, 2 - udział w szkoleniu online organizowanym przez wydawnictwo edukacyjne, 2 wymieniły samodzielne studiowanie literatury i poszukiwanie potrzebnych informacji jako formy doskonalenia, z których czerpały wiedzę na temat SPE. Tematyka szkoleń dotyczyła najczęściej pracy z uczniem z dysleksją, ADHD, z zespołem Aspergera, pracy z uczniem zdolnym oraz z uczniem sprawiającym problemy wychowawcze. Skoro jakość form doskonalenia, w których uczestniczyli nauczyciele, była tak różna, można założyć, że kompetencje zdobyte podczas uczestnictwa w tych formach doskonalenia były także bardzo zróżnicowane.

\footnotetext{
${ }^{9} \mathrm{~W}$ takich przypadkach nauczyciele nie mają obowiązku modyfikowania wymagań stawianych uczniom.
} 


\section{Szkoła jako instytucja}

Szkoła jako instytucja ma zasadniczy wpływ na realizację koncepcji inkluzji. Niekiedy trudno jest oddzielić kompetencje nauczyciela w zakresie pracy z uczniem ze SPE od poziomu przygotowania placówki edukacyjnej i gotow ości do realizowania przez nią koncepcji inkluzji. Jak pokazał przeprowadzony projekt badawczy, placówka edukacyjna często podejmuje działania zmierzające w kierunku podniesienia kompetencji nauczycieli w tym zakresie poprzez oferowanie form doskonalenia zawodowego. Czasami jednak odpowiedzialność za pogłębianie wiedzy i umiejętności spoczywa na nauczycielu. Podobnie jest w przypadku dostosowywania przez nauczycieli poziomu wymagań do możliwości uczniów ze SPE, które może być regulowane przez Wewnętrzny System Oceniania.

W przeprowadzonym badaniu poziom realizacji koncepcji inkluzji przez placówkę edukacyjną został wyrażony poprzez następujące wskaźniki: szkoła posiada wizję kształcenia uczniów ze SPE, nauczyciel przedmiotu jest wspierany przez zespół fachowców, szkoła jest wyposażona w odpowiedni sprzęt i pomoce dydaktyczne, pomocne w pracy z uczniem ze SPE.

W ponad $90 \%$ przypadków nau czyciele twierdzą, że szkoła ma wypracowaną wizję wsparcia ucznia ze SPE. Znamienne jest, że obecność ucznia ze SPE była przez nauczycieli postrzegana w kategoriach problemu, z którym trzeba się zmierzyć w ramach posiadanej wiedzy, umiejętności oraz dostępnych środków (por. tabela 3). Nikt z respondentów nie wskazał na wartość dodaną płynącą faktu, że uczeń ze SPE znajduje się w klasie.

\begin{tabular}{|l|r|}
\hline Wizja szkoły w pracy z uczniem ze SPE & $\begin{array}{r}\% \\
\text { odpowiedzi }\end{array}$ \\
\hline $\begin{array}{l}\text { Organizowanie zajęć dodatkowych (korekcyjno-kompensacyjnych, socjotera- } \\
\text { peutycznych) }\end{array}$ & $35 \%$ \\
\hline $\begin{array}{l}\text { Dostosowanie wymagań i warunków oceniania do zaleceń poradni psycholo- } \\
\text { giczno-pedagogicznej }\end{array}$ & $32 \%$ \\
\hline $\begin{array}{l}\text { Współpraca z rodzicami ucznia (konsultacje dla rodziców, współpraca przy mo- } \\
\text { nitorowaniu pracy w domu) }\end{array}$ & $17 \%$ \\
\hline Tworzenie atmosfery wsparcia & $14 \%$ \\
\hline Inne (organizowanie szkoleń dla nauczycieli) & 2 \\
\hline
\end{tabular}

Tabela 3: Elementy wizji szkoły odnośnie do pracy z uczniem ze SPE w opiniach nauczycieli języków obcych.

Spośród objętych projektem badawczym szkół tylko w jednej nauczyciele nie mieli wsparcia specjalistów. Była to mała szkoła położona w gminie wiejskiej. W pozostałych placówkach zatrudnieni byli pedagodzy (65\%), psychologowie 
Uczeń ze specjalnymi potrzebami edukacyjnymi na lekcji języka obcego...

(62\%) oraz logopedzi (14\%) $)^{10}$. W 13 przypadkach (36\%) podkreślono, że praca z uczniem ze SPE planowana i monitorowana jest przez zespół, którzy współpracuje także często z rodzicami ucznia. W optymalnym przypadku współpraca ta wygląda następująco: „(...) nauczyciel jest wspierany przez pedagoga szkolnego oraz psychologa. Wspólnie monitorują oni postępy ucznia w nauce, dostosowują metody pracy oraz wyznaczają cele na przyszłość. Pedagog służy również wszelką radą i pomocą w przypadku jakichkolwiek problemów lub też wątpliwości ze strony nauczyciela. Pedagog szkolny często kontaktuje się również z rodzicami ucznia, więc na bieżąco jest zorientowany w obecnej sytuacji w domu rodzinnym i przekazuje te informacje nauczycielowi języka angielskiego".

55\% szkół, w których przeprowadzono obserwację, było wyposażonych w sprzęt i materiały dydaktyczne wspierające pracę z uczniem ze SPE. Do najczęściej wymienianych należą: gry językowe (16), tablica interaktywna (11), dodatkowe karty pracy dla uczniów (6), literatura fachowa dla nauczycieli (6), programy edukacyjne (5), komputer z dostępem do Internetu w sali (4).

\section{Dyskusja i wnioski}

Implementacja dydaktyki inkluzyjnej jest procesem złożonym. Przeprowadzony projekt badawczy pokazał, że szkoły podstawowe radzą sobie z dydaktyką włączającą coraz lepiej. Wzrasta też poziom świadomości nauczycieli w tym zakresie, choć wsparcie dla uczniów ze SPE sprowadzają oni często do zabiegów czysto organizacyjnych. Do pozytywnych wyników badania można zaliczyć fakt, że nauczyciele w przeważającej mierze dostosowują materiały, sposób nauczania oraz poziom wymagań do możliwości uczniów ze SPE, oraz to, że w swojej pracy dydaktycznej uwzględniają zalecenia poradni psychologiczno-pedagogicznych i że jest na to kładziony coraz większy nacisk ze strony dyrektorów szkół. Zaznacza się także tendencja - choć ma to miejsce w stopniu wciąż jeszcze niewystarczającym - do nawiązywania współpracy pomiędzy nauczycielami przedmiotu a specjalistami. Współpraca taka jest niezbędna, aby w sposób holistyczny i efektywny wspierać ucznia ze SPE. Żaden z protokołów nie podaje, aby w którejkolwiek z badanych szkół nauczyciele mieli zwyczaj współprowadzenia zajęć czy stosowania superwizji koleżeńskiej. Badanie pokazało także, że większość szkół jest słabo wyposażona w pomoce dydaktyczne i nowoczesny sprzęt, które uczniom ze SPE ułatwiłyby naukę. Tradycyjne klasy szkolne, gdzie lekcje prowadzi się na ogół w systemie frontalnym, bez mobilnych stolików i krzesełek, dodatkowych sal umożliwiających pracę

${ }^{10}$ Wyniki sumują się do ponad 100\%, ponieważ w niektórych szkołach zatrudniony był więcej niż jeden specjalista. 
indywidualną i grupową, utrudniają indywidualizację procesu nauczania. Niepokojący jest też fakt, że nie ma spójnego systemu doskonalenia, ani wymogu regularnego doskonalenia się wszystkich nauczycieli ${ }^{11}$. Zależy to najwyraźniej od inicjatywy dyrektorów szkół (organizowanie szkoleń tematycznych dla rad pedagogicznych) lub samych nauczycieli.

Należy podkreślić wartość dydaktyczną zrealizowanego projektu dla studentów - przyszłych nauczycieli języków obcych. Dzięki ukierunkowanym pytaniom mogli uchwycić różne aspekty związane z nauczaniem uczniów ze SPE w kontekście wdrażania dydaktyki włączającej. W ustnym podsumowaniu projektu studenci wielokrotnie podkreślali ten aspekt. Swoje wnioski dotyczące realizacji dydaktyki inkluzyjnej poczynione na podstawie obserwacji uczestniczącej, przeprowadzonych wywiadów oraz doświadczeń zdobytych w trakcie praktyki mogli podsumować w komentarzach. Na zakończenie warto zacytować jeden z nich: „Uważam (...), iż nauczycielka powinna bardziej zwracać uwagę na to, jak uczniowie (szczególnie chłopcy) odzywają się do ucznia podczas lekcji ${ }^{12}$. Pod żadnym pozorem nie powinna pozwalać na takiego typu komentarze na forum klasy. Szkoła powinna być również bardziej przygotowana na pracę z uczniem o szczególnych potrzebach edukacyjnych, np. w każdej klasie powinien znajdować się podręcznik z powiększoną czcionką, rzutnik i projektor, który umożliwiłby wyświetlanie oraz powiększanie omawianych treści. Nie do końca dobra jest reforma M EN odnośnie wprowadzenia podręczników, w których uczniowie nie mogą pisać (są wypożyczane z biblioteki). Uważam, iż jest to bardzo duże utrudnienie dla uczniów jak ten, mających problem ze sprawnym i poprawnym pisaniem".

\section{BIBLIOGRAFIA}

Al-Khamisy, D. 2013. Edukacja właczajq̨ca edukacja dialogu. W poszukiwaniu modelu edukacji dla ucznia ze specjalnymi potrzebami edukacyjnymi. Warszawa: Wydawnictwo Akademii Pedagogiki Specjalnej.

Al-Khamisy, D. 2015. „System kształcenia nauczycieli jako generator inkluzji edukacyjnej" (w) Edukacja inkluzyjna. Konteksty indywidualistyczne, wspólnotowe i interpersonalne. Część I (red. A. Bałandynowicz, L. Pytka, T. Zacharuk). Siedlce: Wydawnictwo Uniwersytetu Przyrodniczo-Humanistycznego w Siedlcach, str. 13-26.

${ }^{11}$ Po uzyskaniu stopnia nauczyciela dyplomowanego nauczyciel nie ma obowiązku dokumentowania swojego rozwoju zawodowego.

12 Uczeń, o którym mowa, uczęszcza do klasy IV i ma opinię poradni wskazującą na ogólne trudności w uczeniu się. Dotyczą one głównie czytania i pisania: nie czyta płynnie, obniżone jest również zapamiętywanie oraz rozumienie czytanych treści. Obniżona jest także umiejętność pisania w zakresie poprawności ortograficznej oraz graficznej jakości pisma. 
Uczeń ze specjalnymi potrzebami edukacyjnymi na lekcji języka obcego...

Czopińska, M., Szumilas, E. 2015. M odel Lokalnej Wspótpracy na rzecz dzieci ze specjalnymi potrzebami edukacyjnymi. Warszawa: Ośrodek Rozwoju Edukacji. http://www.bc.ore.edu.pl/Content/844/Model_wspolpracy_lokalnej.pdf [DW $=31.12 .2016]$.

Hattie, J. 2015. Widoczne uczenie się dla nauczycieli. Jak maksymalizować siłę oddziaływania na uczenie się. Warszawa: Centrum Edukacji Obywatelskiej.

Karpińska-Szaj, K. 2011. „Uczniowie z niepełnosprawnością w szkołach ogólnodostępnych: nauczanie języków obcych". Neofilolog, 36: 59-72.

Karpińska-Szaj, K. 2013. Nauczanie języków obcych uczniów z niepełnosprawnościq w szkotach ogólnodostępnych. Poznań: Wydawnictwo Naukowe UAM .

Łobocki, M. 2006. M etody i techniki badań pedagogicznych. Kraków: Oficyna Wydawnicza Impuls.

Pachowicz, M. 2011. „Kształcenie integracyjne - moda czy krok milowy edukacji w Polsce" (w) U czeń z niepełnosprawnościq w szkole ogólnodostępnej (red. Z. Gajdzica). Sosnowiec: Oficyna Wydawnicza Humanitas, Wyżzza Szkoła Humanitas, str. 124-131.

Pertek, A., Scheler, S. 2016. Inklusions-M aterial. Klasse 5-10. Berlin: Cornelsen Verlag GmbH.

Reich, K. 2014. Inklusive Didaktik. Bausteine für eine inklusive Schule. Weinheim und Basel: Beltz Verlag.

Scruggs, T., M astropieri, M. A., M cDuffie, K. 2007. "Co-Teaching in Inclusive Classrooms: A Metasynthesis of Qualitative Research". Exceptional Children, 73(4): 392-416. http:// www.schoolturnaroundsupport.org/sites/default/files/resources/Scru gg_2007.pdf [DW $=31.12 .2016]$.

Seredyńska, A. 2013. „Superwizja koleżeńska jako wsparcie w pracy nauczyciela”. Pedagogika Społeczna, 4(50): 99-112.

Szumski, G. 2011. „Teoretyczne implikacje koncepcji edukacji włączającej” (w) Uczeń z niepetnosprawnościq w szkole ogólnodostępnej (red. Z. Gajdzica). Sosnowiec: Oficyna Wydawnicza Humanitas, Wyższa Szkoła Humanitas, str. 13-23.

Warnock, M. 1978. Special Educational Needs. Report of the Committee of Enquiry into the Education of Handicapped Children and Young People. London: Her M ajesty's Stationery Office. http://www.educationengland.org.uk/documents/ warnock/warnock1978.html [DW $=31.12 .2016]$.

Zaremba, L. 2015. Specjalne potrzeby rozwojowe i edukacyjne dzieci i młodzieży. Identyfikowanie SPR i SPE i sposoby ich zaspokajania. Warszawa: Ośrodek Rozwoju Edukacji. http:// www.bc.ore.edu.pl/Content/671/identyfikowanie+spe_spr.pdf [DW $=31.12 .2016]$. 


\section{Załącznik \\ Praca z uczniem o specjalnych potrzebach edukacyjnych}

\section{Realizacja koncepcji inkluzji w polskich szkołach}

Imię i nazwisko studenta, który prowadził obserwację:

Szkoła:

Okres, w którym prowadzono obserwację:

Skąd czerpali Państwo informacje przedstawione w arkuszu?

\section{Pytania dotyczące ucznia}

Klasa: Rodzaj potrzeb edukacyjnych:

Czy uczeń ma opinię/orzeczenie poradni?

TAK NIE

Czy uczeń uczęszcza do klasy integracyjnej?

TAK NIE

Jakie problemy ma obserwowany uczeń na lekcji języka obcego? (Proszę opisać).

\section{Pytania dotyczące nauczyciela języka obcego}

Czy nauczyciel zapoznał się z opinią ucznia, o ile ten takową posiada? TAK NIE Jakie szczególne trudności wskazuje nauczyciel języka obcego w pracy z obserwowanym uczniem?

Czy nauczyciel dostosowuje metody pracy do potrzeb ucznia ze specjalnymi potrzebami edukacyjnymi?

TAK NIE

Jeśli odpowiedziano TAK, proszę wymienić te metody.

Jeśli odpowiedziano NIE, proszę o uzasadnienie, dlaczego.

Czy nauczyciel dostosowuje poziom wymagań i sposób oceniania do możliwości ucznia ze specjalnymi potrzebami edukacyjnymi?

TAK NIE

Jeśli odpowiedziano TAK, proszę opisać, na czym to dostosowanie polega.

Jeśli odpowiedziano NIE, proszę o uzasadnienie, dlaczego.

Czy nauczyciel brał w ciągu ostatnich trzech lat udział w jakichś formach doskonalenia na temat pracy z uczniami o specjalnych potrzebach edukacyjnych? TAK NIE Jeśli odpowiedziano TAK, proszę wymienić te formy doskonalenia. Jeśli odpowiedziano NIE, proszę o uzasadnienie, dlaczego.

\section{Pytania dotyczące klasy, do której uczęszcza uczeń ze specjalnymi potrzebami edukacyjnymi}

llu uczniów ze specjalnymi potrzebami edukacyjnymi uczęszcza do obserwowanej klasy? Ilu ma opinię/ orzeczenie poradni? 
Uczeń ze specjalnymi potrzebami edukacyjnymi na lekcji języka obcego...

Jakie nastawienie ze strony kolegów i koleżanek w stosunku do obserwowanego ucznia można zaobserwować? Czy daje się zaobserwować raczej wsparcie i współdziałanie uczniów, czy też izolowanie ucznia ze specjalnymi potrzebami edukacyjnymi? Proszę o możliwie dokładny opis poparty przykładami.

\section{Pytania dotyczące szkoły}

Czy szkoła ma określoną wizję pracy z uczniami o specjalnych potrzebach edukacyjnych?

TAK NIE

Jeśli odpowiedź brzmi TAK, proszę określić, na czym ta wizja polega.

Czy nauczyciel języka jest wspierany przez innych specjalistów (psychologa, pedagoga szkolnego, nauczyciela pomocniczego)?

TAK NIE

Jeśli odpowiedź brzmi TAK, proszę wymienić, przez kogo i opisać, na czym to wsparcie polega.

Czy szkoła jest wyposażona w odpowiedni sprzęt, pomoce dydaktyczne, materiały pomocne w pracy z uczniem ze specjalnymi potrzebami edukacyjnymi, itp.?

TAK NIE

Jeśli odpowiedziano TAK, proszę wymienić te pomoce.

Komentarz: 